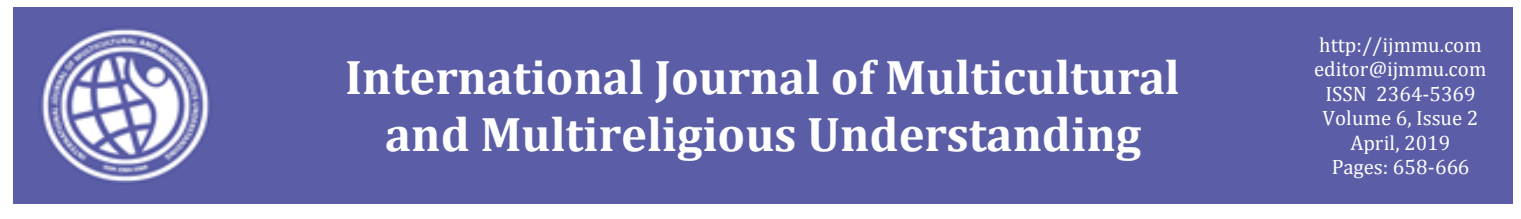

\title{
Legal Protection Against Providers of Guarantees for Land Rights in the event of Default Debtors (Study at Bank Mandiri Bima Branch)
}

\author{
Dina Rahayu Eka Putri; Sudiarto; Aris Munandar \\ Postgraduate program Legal Study and Notaries, Mataram University, Indonesia \\ http://dx.doi.org/10.18415/ijmmu.v6i2.751
}

\begin{abstract}
In the practice of lending at Bank Mandiri, Bima Branch is found by debtors who do not have objects in the form of land rights that can be guaranteed, but banks as creditors can still channel credit due to the appearance of third parties as guarantors, where these third parties are owners of land rights the land rights as collateral for the debtor's credit. This third party is the provider of mortgages in the APHT, as stipulated in Article 8 paragraph 1 of Law No. 4 of 1996 concerning Mortgage Rights. The problem in this research is, how is the responsibility of the guarantee provider of land rights in the event of a default debtor? And how is the legal protection of the guarantee provider of land rights in the event of a debtor's performance? The purpose of this research is to know and analyze the responsibility of the giver of the guarantee of the upper right in the case of default debtors, and to know and analyze legal protection against the giver of the guarantee of land rights in the event of default debtors. This research has benefits both practically and theoretically. The research used in this study is a type of Empirical Normative legal research, and the approach in this study is the Legislative, Conceptual, and Sociological Approaches. The collaterals of land rights are responsible for surrendering the rights to the land voluntarily to the bank to be executed by the bank in the event of a default debtor. Based on preventive legal protection, the guarantee provider of land rights has been protected under the Underwriting Rights Act, contained in Article 12, Explanation of Article 6, and Article 20 paragraph (2), and based on the Bima Bank Mandiri policy, while based on refresive legal protection guarantee providers do not have legal protection because the Underwriting Law has not yet regulated refresive legal protection.
\end{abstract}

Keywords: legal Protection; Provider of Land Rights Guarantee; Default

\section{Introduction}

Improving people's living standards is one aspect that must be continuously programmed by the government to enter this era of development, one of the efforts to improve people's lives is by providing capital to support the community's economic activities, providing capital to the community through banking services. The capital provided by banks to the public is often found in the form of credit.

Guarantees are one of the conditions for debtors to obtain credit facilities from banks, where this guarantee has several functions and one of them is to secure repayment of credit if the debtor defaults. The surrender of collateral by the debtor relates to the credit agreement agreed upon by the parties, so that if the debtor does not submit a guarantee to the bank it will be difficult for the debtor to obtain credit. Guarantees that are widely used to obtain credit facilities are material guarantees in the form of guarantees of land rights, one of which is land is a guarantee that has a stable price even the price has the potential to increase, so that the bank as a creditor will not suffer losses. 
However, in practice, debtors often do not have objects that can be guaranteed in this case, what is meant is collateral in the form of land rights, but banks as creditors can still channel credit due to the appearance of third parties as guarantors, where these third parties are owners of rights. land that gives land rights as collateral for debtor credit. The existence of a third party as the guarantee provider is based on the request of the debtor to borrow proof of the rights to the land owned by a third party as a guarantee of his credit. The third party providing the guarantee will sign the Deed of Giving Rights (APHT), wherein this third party is the giver of mortgage rights. As stipulated in Article 8 paragraph 1 of Law No. 4 of 1996 concerning Mortgage Rights on Land and Objects Relating to Land, which states that: "Provider of Underwriting Rights is an individual or legal entity that has the authority to carry out legal acts against the Underwriting Right object in question."

So the provider of mortgage rights is the owner of the land rights or the owner of the land rights along with the building above the land, the landowner can be the debtor himself or another person or legal entity not the debtor, only the landlord has the right to guarantee mortgage right. ${ }^{1}$ Article 8 is what underlies the bank to allow the debtor to use the guarantee of other people's land rights as collateral for credit, because indeed in this Article it does not require the debtor to be a giver of mortgage rights or as the owner of land rights that will be bound by mortgage rights.

In its implementation, there were several debtors who defaulted on credit agreements with guaranteed rights to land owned by these third parties, this happened at the Bank Mandiri branch of Bima. As a result of the default the bank as the creditor will execute the collateral if within the specified time the debtor still does not have a good intention to repay the debt.

The position of the creditor as the holder of mortgages places the creditor in a favorable position, because the creditor has the right to be preceded in fulfilling the debtor's debt, if the debtor is interpreted because it has been regulated in Article 6 of Law No. 4 of 1996 concerning Mortgage Rights on Land and Objects Relating to Land. While the Third Party as the giver of guarantee of land rights has not yet obtained optimal protection in the Law on the Liability Rights if the debtor defaults.

The formulation of the problem in this study is, 1) How is the responsibility of the giver of the guarantee of land rights in the event of a default debtor? How is the legal protection against the guarantee provider of land rights in the event of a default debtor?

The purpose of this research is to know and analyze the responsibility of the giver of the guarantee of the upper right in the case of default debtors, and to know and analyze legal protection against the giver of the guarantee of land rights in the event of default debtors. This research has benefits both practically and theoretically.

The type of research used in this study is a type of Empirical Normative legal research. Furthermore, the approach used in this study is the Legislative Approach, Conceptual Approach, and Sociology Approach.

\section{Discussion}

\section{Responsibility of the Provider of Guarantees for Land Rights in the case of Default Debtors}

a. Legal Position of the Provider of Guarantees of Land Rights at Bank Mandiri, Bima Branch

Provision of collateral in the credit agreement must be bound by an agreement to bind the guarantee, in the event that the guarantee is in the form of land rights, then the binding of the guarantee uses mortgages, according to Law No. 4 of 1996 concerning Mortgage Rights on Land and Objects Relating to Land, mortgage rights are: "Guaranteed rights imposed on land rights as referred to in Law Number 5 of 1960 concerning Basic Agrarian Principles, hereinafter or not the following other objects

\footnotetext{
${ }^{1}$ Sutarno, Aspek-Aspek Hukum Perkreditan Pada Bank, $5^{\text {th }}$ Print, CV Alfabeta, Bandung, 2014, p. 162
} 
which constitute a unit with the land, for repayment of certain debt, which gives a position which is prioritized to certain creditors to other creditors."

This guarantee binding agreement is an additional agreement (accesoir) of the principal agreement, namely a credit agreement. In general explanation Law No. 4 of 1996 concerning Mortgage Rights on Land and Objects Relating to Land, item 8 states that: "Underwriting rights according to their nature constitute follow-up or accessoir on a certain receivable, which is based on a debt agreement or other agreement, hence the birth and existence are determined by the existence of receivables guaranteed for repayment. In the event that the receivables concerned are transferred to another creditor, the Underwriting Right that guarantees it, because the law is also transferred to the creditor. Likewise, Underwriting Rights are canceled due to the law, if due to repayment or other reasons, the receivables that are guaranteed are deleted."

The existence of the party guaranteeing the rights to this land plays an important role in lending to the debtor, where the giver of the guarantee of the right to land binds him / herself to guarantee the repayment of the debtor's debt. Based on information from Taufik Rahman Wahid, as a micro Mandiri degenerator at the Mandiri branch of Bima Branch: "The binding given by the guarantee provider of this land with the bank, through the Deed of Giving Rights (APHT) and Power of Attorney Selling Collateral, wherein the APHT is Giver guarantee as the provider of mortgage rights, and in the Selling Power of Attorney as the owner of collateral."2

And based on these contracts, there is a legal relationship between the bank and the guarantee provider, and becomes the basis for the involvement of the guarantee provider in giving credit to the debtor, even though the guarantee provider is not the debtor, but the guarantee provider is involved in the contracts related to lending to the debtor.

Then, further in his statement, Mr. Taufik Rahman Wahid, said that: "the legal position of the guarantee giver of this land rights is as a guarantor, said to be a guarantor because the party gives his land rights as collateral for repayment of debtor's debts, and also knows and approve in the credit agreement, then sign the Deed of Assignment (APHT) as the provider of the mortgage and sign the Power of Attorney to Sell Collateral. In addition, the debtor is also a guarantor in repaying the debt, where the debtor also provides guarantees, namely the business of the debtor itself. so that in this credit agreement there are two guarantors, namely the debtor himself and the giver of the guarantee of land rights." ${ }^{3}$

Based on this statement, it is true that when the party granting the guarantee of land rights binds itself to sign the APHT as the provider of mortgage rights, then the party can be said as a guarantor because in the granting of the right of liability preceded by a promise to provide mortgage rights to guarantee certain debt repayments. Regarding this matter, it is regulated in Article 10 paragraph (1) of Law No. 4 of 1996 concerning Mortgage Rights on Land and Objects Relating to Land, which states that: "Granting of Underwriting Rights is preceded by a promise to provide Underwriting Rights as collateral for repaying certain debt, which is stated in and is an inseparable part of the debt agreement or the other debt that caused the debt."

The position of a guarantor in material guarantees is different from the position of the guarantor in individual guarantees / underwriting, where the nature of this material guarantee is not borne, while the nature of the individual/underwriting guarantee is borne and the guarantor can be bankrupt. As well as material guarantees are subject to the specific provisions of material guarantees, while the guarantee of coverage (Borgtocht) is subject to general arrangements in the Civil Code. ${ }^{4}$

Although the function of individual guarantees and material guarantees is the same, namely to guarantee the repayment of debtors' debts, the objects in these guarantees are different, where the objects

\footnotetext{
${ }^{2}$ Interview with Mr. Taufik Rahman Wahid, S.H, as Micro Mandiri Maneger for Bank Mandiri in Bima

Branch

${ }^{3}$ Interview with Mr. Taufik Rahman Wahid, S.H, as Micro Mandiri Maneger for Bank Mandiri in Bima Branch

${ }^{4}$ Hery Shietra, Praktik Hukum Jaminan Kebendaan, Mold 1, PT Citara Aditya Bakti, Jakarta, 2016, p. 127
} 
are specifically separated from the debtor's assets or other parties who have collateral penanggungan (Borgtocht) is all or part of the assets that are now owned by the insurer and will come.

\section{b. Responsibility of the Provider of Guarantees for Land Rights in the case of Default Debtors}

According to the Law Dictionary, default means negligence, negligence, breach of promise, not fulfilling its obligations under the agreement. Default is not fulfilling or negligent in carrying out obligations as specified in the agreement made between the creditor and the debtor. ${ }^{5}$ Default according to Prof. R. Subekti. S.H., can be in the form of four categories: a) Not carrying out what he is able to do; b) Carry out what he promised, but not as promised; c) Do what he promised but late; d) Do something which according to the agreement is not permissible. ${ }^{6}$

Failure to fulfill the obligation (default) can be caused by 2 (two) possibilities, namely: a) Because of the debtor's own mistakes either intentionally or because of negligence; $b$ ) Because the force majeure is beyond the capacity of the debtor. ${ }^{7}$

Risks in granting credit, namely the occurrence of default by one party, especially from the debtor, based on the research conducted by the author there have been several cases of default in the credit agreement at Bank Mandiri Branch Bima. The occurrence of defaults on credit agreements at the Bima Branch of Bank Mandiri, are caused by several things: a) The debtor from the beginning did not have a good intention to fulfill his obligations; b) The debtor business is in trouble; and c) A coercive situation occurs (such as natural disasters and others). ${ }^{8}$

In brief, it can be explained from the Civil Code which also regulates the legal consequences that occur if the obligation is not fulfilled or in other words there has been a default in an agreement, the legal consequences that can be formulated in the Civil Code can be seen in the following article: a) Article 1243 Civil Code contains: "reimbursement of costs, losses and interest because it is not fulfilled an agreement, then began to be required, if the debtor, after being declared negligent fulfilling the agreement, still neglect it, or if something must be given or made, can only be given or made within the grace period has exceeded it. "; b) Article 1237 of the Civil Code which contains: "in the event of an agreement to provide a certain material, the material since the engagement was born, is at the expense of the debtor."; c) Article 1266 of the Civil Code which contains: "Canceled conditions are deemed to always be included in reciprocal agreements, when one party does not fulfill its obligations." 9

When the debtor is determined to have been defaulted by the creditor, the person responsible for this matter is not only the debtor but the other party who also binds himself to the achievement of the debtor's performance, the other party is the guarantor or the material guarantee provider in this case land rights. As explained by Taufik Rahman Wahid, as a micro Mandiri degenerator at Bima Bank Mandiri Branch: "that when a debtor defaults, and the debtor does not have good faith to pay off the remaining debts, the bank will execute the collateral given by the debtor. Where the debtor guarantees his business and land rights. The first thing that will be executed is the debtor's own business, if the debtor's business is insufficient to pay off the debt, the bank will execute other guarantees, namely land rights that have

\footnotetext{
${ }^{5}$ Salim H.S, Hukum Kontrak Teori \& Teknik Penyusunan Kontrak, Sinar Grafika, Jakarta, 2017, p. 98

${ }^{6}$ Johannes Ibrahim, Cross Dafault \& Cross Collateral Sebagai Upaya Penyelesaian Kredit Bermasalah, Mold 1, Refika Aditama, Bandung, 2004, p. 55-56

${ }^{7}$ Ines Age Santika, dkk., Penyelesaian Sengketa dan Akibat Hukum Wanprestasi Pada Kasus Antara PT Metro Batavia Dengan PT Garuda Maintenance Facility (GMF) Aero Asia, Universitas Sebelas Maret, Surakarta, 2015, p. 59.

${ }^{8}$ Interview with Mr. Taufik Rahman Wahid, S.H, as Micro Mandiri Maneger for Bank Mandiri in Bima Branch

${ }^{9}$ Ines Age Santika, dkk., Op. cit., p. 60.
} 
been charged with mortgage rights, where the rights to this land do not belong to the debtor. So that the other party as the land owner is also responsible because of the default of the debtor."10

Where the guarantor is also responsible to creditors, as the owner of the land rights. Furthermore, it was explained by Taufik Rahman Wahid, as a micro Mandiri degenerator at Mandiri Bank Bima Branch: "that the guarantor in the event of a default debtor has the first responsibility to encourage the debtor to have good intentions and immediately pay off the remaining debts, because if the debtor still does not have good intentions, the consequences the bank as a creditor will execute the collateral provided by the guarantor in the form of land rights based on granting rights, and this will be very detrimental to the guarantor. And the second guarantor is responsible for submitting collateral objects, namely land rights at the time of execution without any guarantee from the guarantor ". 11

Regarding the responsibility of the giver of the guarantee of land rights based on his position as guarantor, the author has interviewed one of the guarantor whose debtor has been determined default by Bank Mandiri Bima Branch, in the interview explaining that: , he already knows the risks, and knows the form of his responsibilities, because it has been explained in the contracts signed. But all things are done because the guarantee provider believes the debtor will pay off the credit, so that all the risks and responsibilities will not occur. “12

Further explained by the guarantor: "Because the debtor's debt that has not been paid is not much, there are only a few months left, and the debtor does not have good intention to pay off the debt, so he pays to pay off the debtor's debts at the bank, because the guarantee of land rights is priced higher than the remaining debts of the debtor, so that if the land is executed it will be very detrimental to it." 13

Based on the results of interviews with the guarantor, it can be concluded that, the guarantor's responsibility or guarantee of land rights is if the debtor defaults and does not have good intention to pay off the debt, the guarantor can pay off the debtor's remaining debts if the guarantor does not want the bank executed In other words, the guarantor can choose which form of accountability, whether by surrendering the land to be executed or by helping the debtor to repay the debt so that the land is not executed by the bank.

The responsibility of the guarantor with material guarantees is different from the responsibility of the guarantor with individual guarantees (Borgtoch). Although the guarantor with this material guarantee is also responsible for repaying the debtor's debt but the responsibility does not exceed the guaranteed price of the land rights given, because of its limited liability, limited to the insurance coverage. In contrast to the guarantor's responsibilities with individual guarantees, his responsibilities are unlimited, in the sense that the guarantor's personal assets become the repayment rights of the receivables.

When the debtor defaults the debtor is also responsible with the execution of the debtor's business first, but the guarantor's responsibility is more risky than the debtor's responsibility because in this case the guarantor is not as a debtor but only as a guarantee of land rights to guarantee the debtor's debt repayment, and the guarantee given by the guarantor is higher than the guarantee given by the debtor. So that if the debtor defaults, the party that is most disadvantaged is the guarantor.

\section{Legal Protection Against Providers of Guarantees for Land Rights that Are Not Debtors in the Event of Default Debtors}

Defaults carried out by debtors in their credit agreements, will be very detrimental to third parties as guarantors of land rights in the credit agreement. In the previous chapter, it was explained about the

\footnotetext{
${ }^{10}$ Interview with Mr. Taufik Rahman Wahid, S.H, as Micro Mandiri Maneger for Bank Mandiri in Bima Branch

${ }^{11}$ Interview with Mr. Taufik Rahman Wahid, S.H, as Micro Mandiri Maneger for Bank Mandiri in Bima

Branch

${ }^{12}$ Interview with Mr. Jainuddin, as Guarantor / Giver of Guaranteed Land Rights

${ }^{13}$ Ibid
} 
causes of default by debtors in Bima Bank Mandiri Branch, as well as the responsibility of the guarantor or provider of land rights if the debtor defaults.

However, this responsibility is very detrimental to the guarantor, because the guarantor is not the one who owes, but only as the provider of guarantees of land rights for the interests of creditors and debtors in a credit agreement. therefore the guarantor needs to get a legal protection either by law, the bank as the creditor, or by the debtor.

Regarding the protection of the guarantor, the author will explain the legal protection provided by the Act, Creditors, and debtors to the guarantor. The protection provided is as follows:

\section{a. Legal Protection By Mortgage Rights Law}

In the Underwriting Law, there are indeed many facilities for creditors to return their debts that are stuck in the hands of debtors. However, there are several provisions in the Underwriting Rights Act which also provide protection to the guarantor as the provider of mortgage rights, among others, namely:

1) Article 12: "Promise that gives authority to the Underwriting Right holder to have a Mortgage Right object if the debtor is injured in the promise, null and void by law."

This provision aims to guarantee repayment of debt if the debtor is injured by taking the proceeds from the sale of the collateral object, not for the creditor's ownership as the holder of the mortgage. This provision also protects the interests of the giver of the rights of the arbitrary act of the creditor as the holder of the mortgage. If the giver of the mortgage agrees to give or list the promise that the collateral object will become the property of the creditor if the debtor is injured, this promise by the Underwriting Law is declared null and void. Canceled by law means that from the beginning the promise to have objects was guaranteed if the legal injury was considered never to exist so that it did not need to be carried out.

2) Explanation of Article 6: "The right to sell the Underwriting Right object on its own power is one of the embodiments of the priority position which belongs to the Underwriting Rights Holder or the first Underwriting Right Holder in the event that there are more than one Underwriting Right holder. The right is based on the promise given by the Underwriting Right Provider that if the debtor is injured, the Underwriting Right Holder has the right to sell the Underwriting Right object through a public auction without requiring the approval of the Underwriter and then repaying the loan from the sale before the creditor - another creditor. The remaining sales proceeds remain the right of the Underwriting Right Provider."

In the explanation of Article 6, there is a provision concerning the rights of the giver of the right of ownership, that is, the giver of the right of rights is entitled to the remaining proceeds from the sale of the object of the mortgage.

3) Article 20 paragraph (2): "Based on the agreement of the giver and the holder of the Underwriting Right, the sale of the Underwriting Right object can be carried out under the hand if it will obtain the highest price that benefits all parties."

Based on the provisions in the explanation of Article 6 that the provider of liability has the right to the remaining sale of collateral, then the sale is under the responsibility of providing a solution to fulfill the rights of the giver of rights, by expecting the excess in the proceeds to be the right of the giver.

\section{b. Legal Protection By Bank Mandiri Bima Branch / Creditors as Holders of Underwriting Rights}

The author has conducted an interview with the bank as the provider of mortgage rights regarding legal protection provided by the bank to the guarantor as the provider of mortgage rights, in his statement 
the bank said: "before the guarantor signs the contracts relating to the guarantee of land rights to banks, especially first the bank explained to the guarantor about the risks to be received by the guarantor in a guarantee binding agreement to repay the debtor's debt. this is the first form of protection from the bank to the guarantor. However, if the debtor does not have a good intention, the bank will execute the guarantee given. The guarantee of land rights that is usually carried out by the Mandiri branch of the Bima bank is under the sale. This is done because sales under the hands do not take a long time and do not require expensive fees, because in this case only for business loans, the amount of credit is not large." $" 4$

Based on the statement, that the legal protection mandated by the Law for givers of guarantees has been carried out in practice by Bank Mandiri Bima Branch, where in the Underwriting Rights Act provides protection for the benefit of the parties in Article 20 paragraph (2), and Bank Mandiri Branches run the provision by selling collateral objects under the hand.

\section{c. Legal Protection by Debtors}

In the previous chapter, it was explained about the responsibility of the guarantor, wherein the guarantor helped the debtor to repay the debt so that the land used as collateral was not executed by the bank. Here the author has interviewed the debtor, in his statement the debtor said: "Never intend to conduct defaults which result in detrimental to the guarantor as collateral owner, but in practice the debtor's business experiences problems so that the debtor is unable to repay the debt to the bank, so the debtor asks the guarantor to help repay the debtor's debt so that the guarantees given are not executed by the bank. There is no written agreement between the debtor and the guarantor regarding the agreement, purely borrowing because of a sense of family and mutual trust. Currently the debtor is in installments to replace the guarantor's loss, as a form of responsibility to the guarantor because it has harmed him."15

Based on the statement of the debtor, there is no form of protection given by the debtor to the guarantor, the debtor only provides accountability after the guarantor feels loss. In terms of borrowing a property owned by someone else, the parties should make a strong written agreement and have a legal effect that can be justified, such as making an agreement with an authentic deed or an underhand agreement legalized by a notary. And the debtor as the borrowing party should have good faith to pay off the debt, because he feels responsible for the guarantee provided by the guarantor.

The position of the provider of mortgages is usually very weak when the object of mortgage rights is executed, especially if done forcibly by court order. If the execution is carried out by force, the provider of the mortgage does not have access to the goods sold at auction. Not infrequently, the auction process does not run fair and transparent, so that it harms the giver of the right of ownership as the owner of the object of the mortgage.

Against the loss of the giver of such rights, the Underwriting Law does not regulate in a normative provision. Legal protection for providers of mortgages is not solidly regulated in the Underwriting Rights Act, so the interests of the giver of the rights are often defeated. However, it does not mean that the giver of liability can only be silent if harmed by the creditor due to the execution carried out not in accordance with the applicable provisions. Giving rights holders can still submit rights claims when harmed due to the execution of objects of mortgages. It's just that these facilities and rights are not provided by material law, but are listed in the rules of the Civil Procedure Code (formal law). ${ }^{16}$

\footnotetext{
${ }^{14}$ Interview with Mr. Taufik Rahman Wahid, S.H, as Micro Mandiri Maneger for Bank Mandiri in Bima

Branch

${ }^{15}$ Interview with Ms. Nurhayati, as the debtor

${ }^{16}$ M. Khoidin, Hukum Jaminan ( Hak-hak Jaminan, Hak Tanggungan, dan Eksekusi Hak Tanggungan ), Cet. 2, Laksbang Yustitia, Surabaya, 2017, hlm. 174
} 


\section{Conclusion}

The legal position of the guarantee giver of land rights that is not a debtor is domiciled as a guarantor, this is based on the provisions of Article 10 paragraph (1) of the Underwriting Rights Act, wherein in the Article it is explained that the provision of Mortgage rights is preceded by a promise to provide mortgage rights to guarantee repayment certain debt. Based on his position as a guarantor, the guarantor of this land right is responsible for surrendering the rights to the land voluntarily to the bank to be executed by the bank in the event of default debtors, and the guarantee provider of land rights can also help the debtor to pay off the debt if the land rights are not want to be executed.

Based on the form of preventive legal protection the giver of the guarantee of land rights or guarantor has obtained protection under the Underwriting Rights Act, contained in Article 12, Explanation of Article 6, and Article 20 paragraph (2), and based on the Bank Mandiri policy of Bima Branch inform the giver of the guarantee of land rights in advance regarding the risks and legal consequences of their legal actions before providing a credit facility. However, the giver of the guarantee of land rights does not receive preventive legal protection from the debtor because there is no written agreement in the loan agreement between the two parties. While based on refresive legal protection, the guarantee provider does not have legal protection because the Underwriting Law has not yet regulated refresive legal protection.

\section{Recommendation}

To the bank to provide more stringent rules in granting loans with guaranteed land rights that are not owned by the debtor, so that the guarantee provider is not harmed by the interests of the debtor and creditor. For debtors, as much as possible do not guarantee the rights of land owned by other parties if they feel unable to fulfill their obligations. And for providers of guarantees of land rights to be more considerate of the legal consequences and losses if you want to lend their land to be used as collateral for credit.

In the future, the Underwriting Law can provide refresive legal protection to providers of liability who feel disadvantaged by recipients of mortgage rights. As well as between the debtor and the guarantee party, it is better to make a written agreement with an authentic deed regarding the loan agreement for land certificates for credit guarantees, in order to provide legal protection for parties who feel disadvantaged.

\section{References}

\section{Books}

Hery Shietra. (2016). Praktik Hukum Jaminan Kebendaan. Mold 1. PT Citara Aditya Bakti, Jakarta.

Johannes Ibrahim. (2004). Cross Dafault \& Cross Collateral Sebagai Upaya Penyelesaian Kredit Bermasalah. Mold 1. Refika Aditama, Bandung.

M. Khoidin. (2017). Hukum Jaminan ( Hak-hak Jaminan, Hak Tanggungan, dan Eksekusi Hak Tanggungan ). 2nd print. Laksbang Yustitia, Surabaya.

Salim H.S. (2017). Hukum Kontrak Teori \& Teknik Penyusunan Kontrak. Sinar Grafika, Jakarta. Sutarno. (2014). Aspek-Aspek Hukum Perkreditan Pada Bank. 5th print. CV Alfabeta, Bandung. 
Regulations

Code of Civil law.

Law No. 7 of 1992 concerning Banking.

Law No. 10 of 1998 concerning Amendment to Law No. 7 of 1992 concerning Banking.

Law No. 4 of 1996 concerning the Right to Underwrite Land and Objects Related to Land.

\section{Copyrights}

Copyright for this article is retained by the author(s), with first publication rights granted to the journal. This is an open-access article distributed under the terms and conditions of the Creative Commons Attribution license (http://creativecommons.org/licenses/by/4.0/). 